\title{
Key Management Skills for Integral Civil Engineering Education
}

\author{
https://doi.org/10.3991/ijep.v11i1.15259 \\ Miguel A. Gómez ${ }^{(凶)}$, Rodrigo F. Herrera, Edison Atencio, \\ Felipe C. Muñoz-La Rivera \\ Pontificia Universidad Católica de Valparaíso, Valparaíso, Chile \\ miguel.gomez.fepucv.cl
}

\begin{abstract}
Architecture, Engineering, and Construction (AEC) industry requires many interactions between professionals in different areas. Thus, project managers in the AEC industry should have a set of management-aligned skills. International agreements and accreditation boards state the expected skills for engineering graduates, but they usually overrate technical skills. This study aims to identify the most relevant skills in management for civil engineer's education. To achieve this, a literature review was carried out, and a list of 129 competencies was obtained. This list was summarized in 34 competencies, and his importance level was evaluated using a web-based survey, targeted to Chilean project managers and civil engineers. The collected skills were classified in management, technical and soft skills. According to respondents, the 34 skills described in this paper are important for the exercise of the profession. However, the most important skills in relative terms are soft skills, then management, and finally, technical skills.
\end{abstract}

Keywords - AEC industry, civil engineering education, competencies, management skills

\section{Introduction}

The Architecture, Engineering, and Construction (AEC) industry is characterized for its fragmentation into many fields of specialization, each one of which takes part in the different phases of the product lifecycle [1], [2]. Even though this fragmentation leads to higher levels of professional expertise in every area, and improves the local performances, the increase of parts in which the project is divided creates more and more complex interactions between the professionals [3]. Thus, to improve the global performance, high levels of collaboration and interactions get necessary, in order to achieve a better understanding between every area.

Weak interactions between workgroup members can lead to deficient performance levels, both in every project phase (design, construction, maintenance, operation, deconstruction) and at the global level in the product lifecycle [4]. Poor performance is caused by the realization of non-value-adding activities, which generate waste to the project (reworks, waiting times, among others) [5], and affect the entire project 
productivity [6]. Therefore, project managers and planners should have a set of essential management-aligned competencies [7] that allows them to maximize the product/service value generated by their projects through a systematic waste reduction [6].

Management skills and competencies are highly recommended by the main international accords in the engineering education context and demanded by the main accreditation boards. To demonstrate knowledge and understanding of management, decisionmaking, project leadership, interdisciplinary work, effective communication, and contextual empathy concepts allow the graduates to insert and participate in their projects actively [8]. Within the Accreditation Board for Engineering and Technology criteria is stated that graduates should have a global vision of the engineering problems, considering technical, cultural, social, economic, safety, and wellness aspects; the capability to communicate effectively, recognize their ethical responsibilities, work as effective team members in collaborative and inclusive environments; and high self-management abilities [9]. The criteria and guidelines of the European Network for Accreditation of Engineering Education state as teaching areas for engineering, non-technical evaluation aspects, applicable to the analyses and designs in engineering, and the necessary knowledge in economic, organizational, management, communication, and teamwork issues [10].

In this context, there is an increasing offer of management training for engineers from higher education institutions. These programs seek to strengthen the capabilities and skills associated with project management in its many edges, covering the demand of the companies for integral professionals [11].

As stated above, there is a large volume of competencies aligned with project management; however, there is no study that seeks to prioritize the competencies that should be developed in civil engineering degree programs. Indeed, many of the research carried out to state the skills and competencies that are fundamental for civil engineers, is focused in identifying the differences between the accreditation institutions criteria for the science and technology programs all over the world, and recognize if they are appropriate for the requirements of the 21st-century engineering [12]-[17]. The most cited accreditation institutions and boards, namely ABET, Accreditation Agency for Degree Programmes in Engineering, Informatics, Natural Sciences and Mathematics (ASIIN), American Society of Civil Engineers (ASCE), the European Network for Accreditation of Engineering Education (ENAEE), and Engineers Australia, have very similar criteria [16], in particular, those related to the student outcomes. However, they are quite generic, as they have to apply to many engineering areas. Skills like "the ability to function in multidisciplinary teams" (ABET), "communicate effectively" (ABET), "organize and evaluate concepts and planning procedures [...]" (ASIIN), "develop concepts in team [...]" (ASIIN) and "to demonstrate knowledge and understanding of engineering management principles, and economic decision-making [...]" (Engineers Australia), are some examples of management-aligned competencies, present in the student-outcomes criteria of some of the mentioned accreditation boards and institutions, for engineering programs.

Nevertheless, some researchers have observed the accreditation institutions trend to overrate the technical competencies in detriment of the others, setting the focus in the contents, and not in the thought process that has to be carried out by an engineer [18]- 
[20]. This can be detrimental to students, who end up their studies with a large set of technical skills but lacking management and key transferable skills, which are essential to their professional development and labor insertion [21]. For this reason, identifying the most valued-by-employer skills and competencies has become a main issue, also considering the increasing demand for non-technical or behavioral skills like oral or written communication.

In this context, this study aims to determine which are the main management skills that civil engineers should have, and how they can be classified, according to recent literature. Also, we seek to evaluate what are the competencies that should be prioritized in the formation of engineers, according to experts and practitioners of engineering management.

\section{Research Method}

The present study is divided into three steps, as summarized in Figure 1. In the first step, a literature review was carried out to gather a list of skills and competencies required for project management civil engineers. The search was mainly concentrated, but not exclusively made in review papers (Web of Science and Scopus libraries), accreditation and other engineering education boards and committees, and main conference proceedings between 2004 and 2019. The search topics were: "engineering education", "competencies and skills in civil engineering", "engineering management skills", and "student outcomes for accreditation criteria". As a second step, the authors made a categorization and condensation of the list of skills and competencies. The categories in which the competencies are divided is also defined according to the literature review. The third step consists of the design, planning, and implementation of a survey, where practitioners civil engineers in Chile answered the level of importance of each condensed skill. The results of the survey are latter analyzed using the Relative Importance Index, as defined by [22].

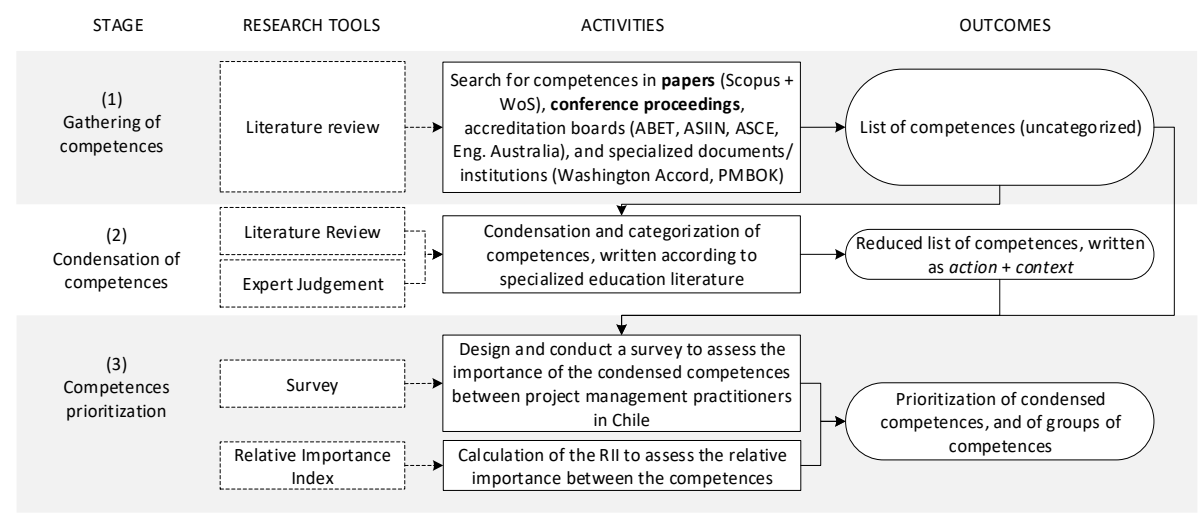

Fig. 1. Research method. 
All the collected competencies can be grouped in the defined categories, which results in a $16.81 \%$ of management skills (MS), $40.71 \%$ of technical skills (TS) and $42.48 \%$ of soft skills (SS). As expected, it can be observed a very high conceptual similitude between some of the competencies retrieved. Then, by expert judgment, a reduction process was carried out, consisting of grouping the similar competencies in just one. According to [23], an effective competence needs three parts:

1) A verb that describes an observable action

2) A context in which the action is to be carried out

3) The acceptable performance levels

Since it is not the intention of this study to provide a scale to evaluate students, the performance level is not included, so the competencies only consist of the action and the context.

Then, from 129 skills, the list was reduced to 34. After the grouping of similar competencies and dividing them into the three defined categories, the distribution results in a $23.53 \%$ of management skills (MS), $35.29 \%$ of technical skills (TS), and $41.48 \%$ of soft skills (SS). Tables 1 to 3 present the management, technical, and soft skills and competencies, respectively, and the corresponding references.

\subsection{Management skills (MS)}

As stated above, management skills include all the non-technical skills directly related to the project management context. For example, "to delegate authority", "group creation and administration", "human resources management", "understanding the role in a group", are all individual skills related to the competence MS8 in Table 1: "Plans, organizes and directs the efforts of one or more work teams". Also, contextual knowledge of the project is included in this category, with competencies MS6 and MS7. MS6 involves the knowledge of the local population and a wide range of stakeholders' commitments. In MS7, are grouped skills like: "Project orientation", "project knowledge", "to know how the project success is measured" and "to know the available resources".

Knowledge about business and public administration (MS3), procurement and contract (MS2), forms and documents (MS4), problem-solving (MS5), and sustainable processes (MS1) are also non-technical skills and competencies that are closely related to project management and then included in this category. 
Table 1. Organizational and management skills

\begin{tabular}{|c|c|c|c|}
\hline Type & Code & Competence & References \\
\hline \multirow{8}{*}{$\begin{array}{l}\text { Organizational and } \\
\text { Management Skills }\end{array}$} & MS1 & $\begin{array}{l}\text { Understand and applies the principles of sustainable } \\
\text { design in his/her professional practice }\end{array}$ & {$[8],[16],[24],[25]$} \\
\hline & MS2 & $\begin{array}{l}\text { Possesses and applies up-to-date procurement and con- } \\
\text { tract knowledge in the preparation of the project tech- } \\
\text { nical documents }\end{array}$ & [15], [24], [26], [27] \\
\hline & MS3 & $\begin{array}{l}\text { Knows and applies business and public administration } \\
\text { concepts and processes in project planning and control }\end{array}$ & $\begin{array}{c}{[8],[16],[25],[26],} \\
{[28],[29]}\end{array}$ \\
\hline & MS4 & $\begin{array}{l}\text { Knows the appropriate forms and documents to incor- } \\
\text { porate into the planning of a project }\end{array}$ & [24], [26], [28] \\
\hline & MS5 & $\begin{array}{l}\text { Is capable to identify and analyze problems, and the } \\
\text { roots of a problem, to design and implement a solution }\end{array}$ & $\begin{array}{l}{[8],[15],[16],[24],} \\
{[26]}\end{array}$ \\
\hline & MS6 & $\begin{array}{l}\text { Is skillful in identifying the commitments of a wide } \\
\text { range of stakeholders in the development of a project }\end{array}$ & $\begin{array}{c}{[8],[20],[24],[26],} \\
{[28]} \\
\end{array}$ \\
\hline & MS7 & $\begin{array}{l}\text { Understands the objectives, limitations, and scope of a } \\
\text { project in a global context }\end{array}$ & {$[24],[26],[27],[29]$} \\
\hline & MS8 & $\begin{array}{l}\text { Plans, organizes and directs the efforts of one or more } \\
\text { work teams }\end{array}$ & $\begin{array}{c}{[8],[15],[20],[24],} \\
{[26]-[29]}\end{array}$ \\
\hline
\end{tabular}

\section{$2.2 \quad$ Technical skills}

In this category are included the competencies related to the theoretical framework of the project manager. As a consequence of this definition, all of the skills here mentioned can be trained in traditional expositive classes. As an example, TS12 "Understand project management methods, processes and procedures", includes knowledge in standard up-to-date management processes, the project management context, and organizational structures. The other competencies cover knowledge in: execution of experiments to processes improvement (TS1), math and basic sciences (TS2), processes and engineering design (TS3), PMBOK 10 areas (TS4), foreign language (TS5), special discipline techniques (TS6), use of technologies and computer software (TS7), quality standards and norms (TS8), new techniques and tools (TS9), tools for performance assessment of projects (TS10), and multidisciplinary approach to engineering (TS11).

Table 2. Technical skills

\begin{tabular}{|c|c|c|c|}
\hline Type & Code & Competence & References \\
\hline \multirow{6}{*}{$\begin{array}{l}\text { Technical } \\
\text { Skills }\end{array}$} & TS1 & $\begin{array}{l}\text { Designs, executes and interprets experiments that allow him/her } \\
\text { to apply the results in the improvement of processes }\end{array}$ & $\begin{array}{l}{[8],[9],[16],[25]} \\
{[28],[29]}\end{array}$ \\
\hline & TS2 & $\begin{array}{l}\text { Selects and applies knowledge and techniques of physical sci- } \\
\text { ences and mathematics in engineering problem solving }\end{array}$ & $\begin{array}{l}{[8],[9],[15],[16]} \\
{[20],[25],[28],[29]}\end{array}$ \\
\hline & TS3 & $\begin{array}{l}\text { Design systems, components or processes to solve engineering } \\
\text { problems }\end{array}$ & $\begin{array}{c}{[8],[9],[15],[16]} \\
{[20],[25],[28]}\end{array}$ \\
\hline & TS4 & $\begin{array}{l}\text { Understand the processes and techniques of the ten areas of pro- } \\
\text { ject management knowledge (PMBOK) }\end{array}$ & {$[8],[24],[26],[27]$} \\
\hline & TS5 & $\begin{array}{l}\text { Speaks and understands more than one language, in a technical } \\
\text { context }\end{array}$ & [16] \\
\hline & TS6 & $\begin{array}{l}\text { Selects and applies the appropriate knowledge and techniques of } \\
\text { his/her discipline in engineering problem solving }\end{array}$ & $\begin{array}{c}{[8],[15],[16],[24],} \\
{[25],[29]}\end{array}$ \\
\hline
\end{tabular}




\begin{tabular}{|c|c|l|c|}
\hline Type & Code & \multicolumn{1}{|c|}{ Competence } & References \\
\hline & TS7 & $\begin{array}{l}\text { Knows and applies available computer technologies for planning } \\
\text { and project management }\end{array}$ & $\begin{array}{c}{[8],[15],[16],[24],} \\
{[26]}\end{array}$ \\
\cline { 2 - 4 } & TS8 & Knows the quality standards and norms to work on & $\begin{array}{c}\text { [8], [16], [24], [27]- } \\
{[29]}\end{array}$ \\
\cline { 2 - 4 } & TS9 & $\begin{array}{l}\text { He/She quickly adapts to the new tools available for the exercise } \\
\text { of his/her profession }\end{array}$ & {$[9],[24],[25]$} \\
\cline { 2 - 4 } & TS10 & $\begin{array}{l}\text { He/She can analyze the performance of a project in a systematic } \\
\text { and judicious way }\end{array}$ & {$[15],[16],[28]$} \\
\cline { 2 - 4 } & TS11 & $\begin{array}{l}\text { He/She possesses a multidisciplinary knowledge that allows } \\
\text { him/her to understand the project as a whole }\end{array}$ & $\begin{array}{c}{[8],[9],[16],[28],} \\
{[29]}\end{array}$ \\
\cline { 2 - 4 } & TS12 & $\begin{array}{l}\text { Understand project management methods, processes, and proce- } \\
\text { dures }\end{array}$ & {$[24],[26],[29]$} \\
\hline
\end{tabular}

\subsection{Soft skills}

This category includes the behavioral component expected from a project management engineer. Local context knowledge (SS1), professional attitudes (SS2), social awareness (SS3), long-life learning (SS4), improvisation (SS5), confidence (SS6), feedback provision and receiving (SS7), decision-making (SS8), adequate contact for requirements (SS9), negotiation (SS10), proactivity and creativity (SS11), team working (SS12), ethical behavior (SS13) and effective communication (SS14) are the concepts that resume the condensed soft skills gathered from the literature review. These competencies are detailed in Table 3 , with their corresponding references.

Table 3. Soft Skills

\begin{tabular}{|c|c|c|c|}
\hline Type & Code & Competence & References \\
\hline \multirow{12}{*}{$\begin{array}{l}\text { Soft } \\
\text { Skills }\end{array}$} & SS1 & $\begin{array}{l}\text { He/She is constantly updated to the local context throw newspapers, } \\
\text { social networks, etc. }\end{array}$ & $\begin{array}{l}{[9],[15],[16],[24],} \\
{[27]}\end{array}$ \\
\hline & $\mathrm{SS} 2$ & $\begin{array}{l}\text { Recognizes and demonstrates attitudes that contribute to the practice } \\
\text { of his/her profession }\end{array}$ & {$[15],[25]-[28]$} \\
\hline & SS3 & $\begin{array}{l}\text { Recognizes the impacts of engineering solutions in a social and } \\
\text { global context }\end{array}$ & $\begin{array}{c}{[8],[15],[16],[24],} \\
{[26],[28]} \\
\end{array}$ \\
\hline & SS4 & $\begin{array}{l}\text { Recognizes the importance of continuous self-directed professional } \\
\text { development, according to his/her needing }\end{array}$ & $\begin{array}{c}{[8],[9],[15],[16]} \\
{[26],[28],[29]} \\
\end{array}$ \\
\hline & SS5 & $\begin{array}{l}\text { He/She can intuit and improvise a quick solution to project manage- } \\
\text { ment related problems }\end{array}$ & {$[15],[24],[26]$} \\
\hline & SS6 & $\begin{array}{l}\text { Acts with confidence in the face of ambiguity, changes and adverse } \\
\text { situations that may arise in the directions of a project }\end{array}$ & {$[15],[24],[26],[27]$} \\
\hline & SS7 & $\begin{array}{l}\text { Accepts and provides feedback in a constructive and considered man- } \\
\text { ner }\end{array}$ & {$[15],[16],[26]$} \\
\hline & SS8 & $\begin{array}{l}\text { Makes decisions with confidence and prior knowledge of the conse- } \\
\text { quences when required }\end{array}$ & {$[8],[15],[24],[26]$} \\
\hline & SS9 & Know who to contact in case of a question or requirement & {$[24],[26]$} \\
\hline & SS10 & Possesses negotiation skills for conflict resolution & {$[15],[24],[26]$} \\
\hline & SS11 & $\mathrm{He} / \mathrm{She}$ is proactive, creative and innovative in problem solving & $\begin{array}{l}{[8],[9],[15],[16],} \\
{[24]-[26]}\end{array}$ \\
\hline & $\mathrm{SS} 12$ & Works effectively as a member or leader of a technical team & $\begin{array}{c}{[8],[9],[15],[16],} \\
{[24]-[29]} \\
\end{array}$ \\
\hline
\end{tabular}




\begin{tabular}{|c|c|l|c|}
\hline Type & Code & \multicolumn{1}{|c|}{ Competence } & References \\
\hline \multirow{2}{*}{} & SS13 & $\begin{array}{l}\text { Understands and undertakes to act ethically, responsibly and respect- } \\
\text { fully in the personal, social, cultural and professional contexts }\end{array}$ & $\begin{array}{c}{[8],[9],[15],[16],} \\
{[24]-[26],[29]}\end{array}$ \\
\cline { 2 - 4 } & SS14 & $\begin{array}{l}\text { Communicates effectively and confidently both orally and in writing, } \\
\text { in technical and non-technical environments }\end{array}$ & $\begin{array}{l}{[8],[9],[15],[16],} \\
{[20],[24]-[27],[29]}\end{array}$ \\
\hline
\end{tabular}

\section{Survey: Relative Importance of Management / Technical / Soft Skills}

To define the most important skills and competencies, it was designed and conducted a web-based survey, in which the respondents (project managers and Civil Engineers practitioners), had to select an absolute importance level for every competency in a Likert scale format ranging from 1 to 5 , where 1 represents null importance, and 5 represents that the competence is imperative. To avoid respondents bias, the competencies were not grouped in the survey, but it was only given a list of the 34 written competencies.

A total of 104 complete surveys were fully answered. Background information about respondents of the survey is presented in Table 4. Most of the respondents have more than ten years of experience $(41.35 \%)$. Additionally, $75.0 \%$ of the respondents are male, and $25.0 \%$ are female.

Table 4. Survey background information

\begin{tabular}{|c|c|c|c|c|c|}
\hline \multirow{2}{*}{ Gender } & \multicolumn{4}{|c|}{ Respondents experience (Years) } & \multirow[b]{2}{*}{ Total } \\
\hline & 0 to 2 & 2 to 5 & 5 to 10 & $10+$ & \\
\hline Male & 12 & 15 & 16 & 35 & $78(75.0 \%)$ \\
\hline Female & 7 & 6 & 5 & 8 & $26(25.0 \%)$ \\
\hline Total & $19(18.27 \%)$ & $21(20.19 \%)$ & $21(20.19 \%)$ & $43(41.35 \%)$ & $104(100 \%)$ \\
\hline
\end{tabular}

Relative importance index (RII) analysis was selected in this study to rank the criteria according to their relative importance [22]. Equation 1 is used to determine the relative index:

$$
R I I=\sum \frac{w}{A \times N}
$$

Where $w$ is the assigned weighting by each respondent (1 to 5), $A$ is the highest weighting possible (5), and $N$ is the total number of the sample (104). The RII was calculated for all of the 34 competencies. Figures 2,3 and 4 show the relative importance index (RII) for all the surveyed competencies, divided into the three already defined categories, management skills (MS), technical skills (TS), and soft skills (SS), respectively. 


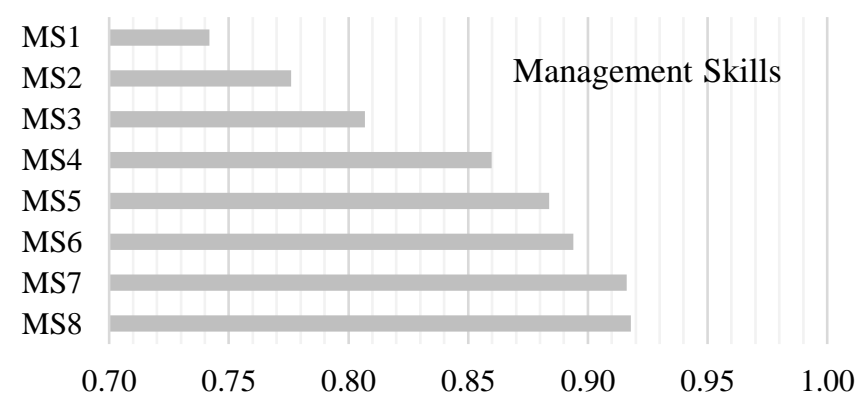

Fig. 2. Relative importance index obtained for management skills

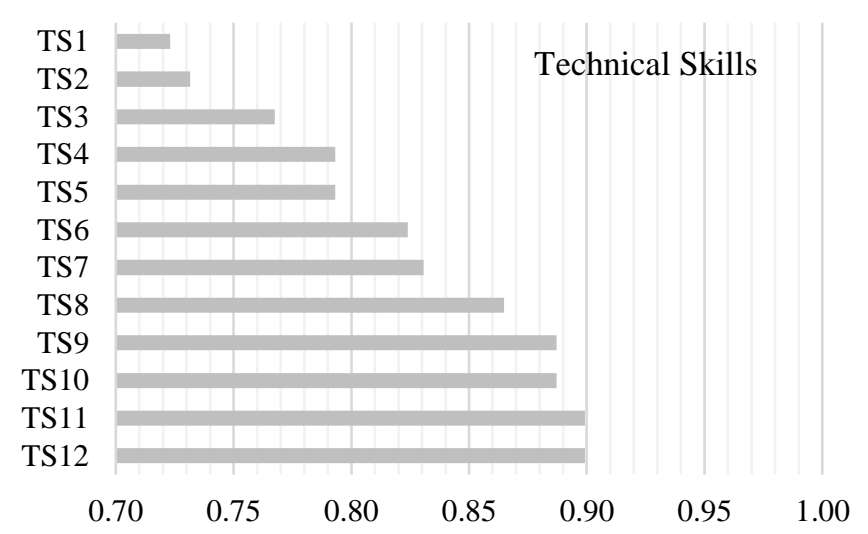

Fig. 3. Relative importance index obtained for technical skills

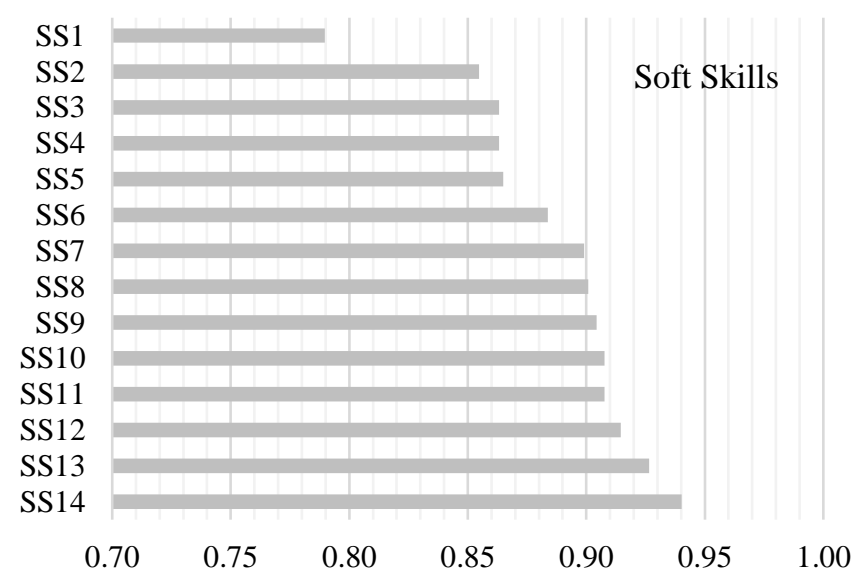

Fig. 4. Relative importance index obtained for soft skills 


\section{Discussion}

Within the management skills (Figure 2), the most important are those related to the organization of teams, project management, commitment management, and problemsolving. These competencies are undoubtedly key in day-to-day civil engineering, and it is consistent with other authors [27], [30]. On the other hand, competencies associated with administrative procedures and processes have a lower RII, since these are more specific to each organization, therefore, what is required is that the professional can quickly learn the procedures of the organization. The main cause of attention is that the competency with the lowest RII is aligned with the application of sustainability principles. This is worrying in a global world where sustainability has to be a fundamental element in the development of engineering.

Among the most important technical skills (Figure 3) are understanding project management methods, multidisciplinary knowledge, performance analysis, and learning new tools and technologies. Once again, there are elements associated with interaction with different professionals, and the capacity for self-learning, elements that are very important in a globalized and fast-moving world. The competencies with a lower RII are those that respond to specific topics of engineering areas, so it is understood that they are not so important for the sample of professionals who answered the survey.

The competencies of the soft skills category are those that have the highest RII compared to the other categories. Within this category, those associated with effective communication, ethical and respectful behavior with the environment, leadership, and proactivity stand out. Interestingly, the competency related to respect society and the environment has one of the highest RIIs while applying a sustainable design has one of the lowest. This may be since the principles of sustainability are still at a strategic level that has not been able to decant what an operational design is. Therefore, the importance of sustainable development is highly valued at the conceptual level but has yet to be implemented in practice. This may change as sustainability concepts are added to programs for new students. Regarding this issue, in [31] is demonstrated how a projectbased approach can develop management skills while raising awareness of sustainability concepts in the early stages of an engineering course.

The results indicate that all of the surveyed competencies have a high relative importance index, beyond 0.7 . Then, all of the presented plots were scaled to start the abscise axis in 0.7 to emphasize the differences. As it can be observed, $100 \%$ of the competencies have a relative importance index beyond 0.7 . Figure 5 shows the percentage of skills by category that has an RII greater than $0.7,0.8$, and 0.9 , respectively. The amount of soft skills (SS) with a relative importance index greater than 0.8 and 0.9 is greater than the number of technical and management skills that meet the same requirement. Also, this same behavior makes management skills prevail over technical. This trend highlights the fact that soft skills are seen as the key skills to develop management and technical expertise, and also that they are the most difficult-to-train group of competencies, which is consistent with the accreditation institutions trend to overestimates technical over behavioral skills. Thus, efforts have been concentrated over the past years into form engineers to develop technical skills, neglecting the soft ones. 


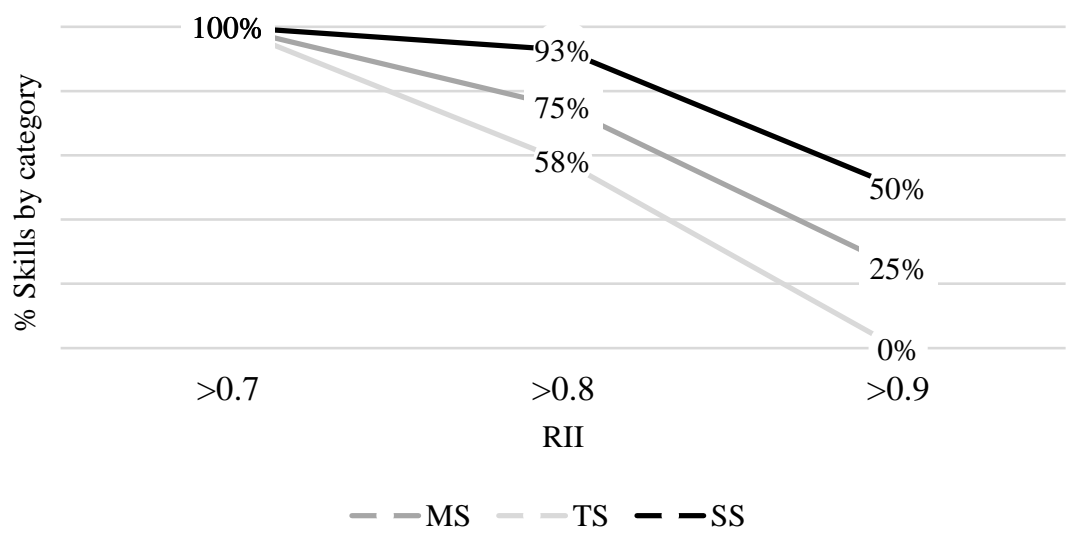

Fig. 5. Percentage of skills over an RII by category

If a cutoff is taken in the RII of 0.9 , there is no technical skill whit such relative importance. The most important technical skills are the understanding of project management methods (TS12), and the multidisciplinary knowledge (TS11), both with an RII of 0.899 . Then, employers seek professionals with a multidisciplinary approach to civil engineering, capable of using existent project management methods to coordinate the team efforts. This role is more evident, considering the management skills with an RII greater than 0.9. Indeed, to plan and organize the efforts of a team (MS8) is the most important of this group, with an RII of 0.918 , and is clearly related to multidisciplinary teamwork, closely followed by the contextual knowledge of the project (MS7), with an RII of 0.916.

From the soft skills, a larger number of competencies have an RII greater than 0.9 than for the other categories. The most important skills of this group, and their corresponding RIIs are: Decision making (SS8), 0.900; consulting (SS9) 0.904; negotiation for conflict resolution (SS10), 0.908; proactivity and innovation (SS11), 0.908; effective teamwork (SS12), 0.915; ethical behavior (SS13), 0.926; and effective communication (SS14), 0.940. Again, these skills are related to teamwork and multidisciplinary problem solving, except for SS13, which is most concerns a value system, and the emotional intelligence of the engineer. Why is it so important to behave ethically, for the success of a project? This is currently a subject of study. A recent study performed in Pakistan shows that general fairness, quality of the treatment, and ethical behavior can reduce the contractors' potential to claims [32]. There is evidence that even students see professional ethics as a key factor in their future professional development, and that it should be included in their engineering courses [33]. Even though ethics is seen as a key competence, there is not yet much interest in investigating its effects, both in the construction industry and in other productive activities [34]. 


\section{Conclusion}

There were 129 competencies/skills aligned with the management that civil engineers are required to hold. This list of 129 can be reduced to 34 competencies that managed to classify in three groups: Management skills, technical skills, soft skills. According to civil engineering practitioners, the 34 skills described in this paper are important for the exercise of the profession, being the range of RII in all cases greater than 0.7. However, the most important group of skills in relative terms is soft skills, then management, and finally, technical skills. This can be attributed to the fact that soft skills are the engine of change to develop management and technical skills, being the most important TS and MS-related also to teamwork and multidisciplinary problem-solving. Indeed, among the most important skills are effective communication, team leadership and multi-disciplinary interaction, proactivity and self-learning, and the use of project management tools, which can be seen as the key skills required of a project management engineer today. To act ethically in the professional environment is also a very valuable skill, and can help to improve the project performance, but still more research is being necessary to clearly assess and understand the effects of ethics in the AEC industry.

This study allows civil engineering academics to prioritize the competencies that are key to the development of civil engineering students and empirically demonstrate that soft skills are a necessity of the professional world. The results presented herein

As mentioned in the research methodology, the survey was answered by 104 practitioners, all from Chile. This corresponds to a limitation of this study, so the new stages of this work consist of

1) Internationalize the survey, also seeking to increase the sample, and

2) Analyze other possibilities of questions in the survey, to make more visible the differences in prioritization.

\section{Acknowledgement}

This research is funded by Project CORFO 14ENI2-26905 Ingeniería 2030-PUCV and housed in the Collaborative Group of Engineering Education of the Pontificia Universidad Católica de Valparaiso. The doctoral studies of R. Herrera are financed by CONICYT-PCHA/National Doctorate/2018 - 21180884. Muñoz's doctoral studies are financed by CONICYT-PCHA/International Doctorate/2019 - 72200300. The doctoral studies of E. Atencio are financed by the Pontificia Universidad Católica de Valparaíso.

\section{$7 \quad$ References}

[1] Dainty, A., Leiringer, S., Fernie, S., and Harty, C. (2017). BIM and the small construction firm: a critical perspective. Building Research and Information, vol. 45, no. 6, pp. 696-709. https://doi.org/10.1080/09613218.2017.1293940 
[2] Love, P., Irani, Z., Cheng, E., and Li, H. (2002). A model for supporting inter-organizational relations in the supply chain. Engineering Construction \& Architectural Management, vol. 9, no.1, pp. 2-15. https://doi.org/10.1046/j.1365-232x.2002.00225.x

[3] Thomas, S., and Tang, Z. (2010). Labour-intensive construction sub-contractors: Their critical success factors. International Journal of Project Management, vol. 28, no. 7, pp. 732740. https://doi.org/10.1016/j.ijproman.2009.11.005

[4] Baiden B., Price, D., and Dainty, A. (2006). The extent of team integration within construction projects. International Journal of Project Management, vol. 24, no. 1, pp. 12-23. https:// doi.org/10.1016/j.ijproman.2005.05.001

[5] Aziz, R. and Hafez, S. (2013) Applying lean thinking in construction and performance improvement. Alexandria Engineering Journal, vol. 52, no. 4, pp. 679-695. https://doi.org/ 10.1016/j.aej.2013.04.008

[6] Dave, B. Koskela, L., Kiviniemi, A, Owen, R., and Tzortzopulos, P. (2013). Implementing Lean in Construction. CIRIA, Classic House, 174-180 Old Street. London, ECIV 9BP, UK. ISBN: 9780860177272.

[7] Herrera, R., Calahorra, M. and Cordero, J. (2016). Principales competencias que debe poseer un director de proyectos en la industria de la construcción. Gaceta Técnica, vol. 16, no. 1, pp. 117-127.

[8] Washington Accord (2014). 1989 - 2014 Celebrating International Engineering Education Standards and Recognition. International Engineering Alliance.

[9] ABET (2018). Criteria for accrediting engineering programs. Engineering Accreditation Commission.

[10] ENAEE (2008). EUR-ACE Framework Standards for the Accreditation of Engineering Programmes.

[11] Muñoz-La Rivera, F. Herrera, R. and Vielma, J. (2018). Importancia de la enseñanza colaborativa en entornos universitarios como respuesta a la fragmentación de la industria de la Arquitectura, Ingeniería y Construcción. XXXI Congreso SOCHEDI, Viña del Mar, Chile. https://doi.org/10.4067/s0718-50732016000200006

[12] Swenty, B., and Swenty, M. (2018). The impact of EAC-ABET program criteria on civil engineering curricula. ASEE Annual Conference and Exposition, Conference Proceedings, 2018-June, Salt Lake City, Utah, USA. https://doi.org/10.18260/1-2--31106

[13] Anwar, A., and Richards, D. (2018). Comparison of EC and ABET Accreditation Criteria. Journal of Professional Issues in Engineering Education and Practice, vol. 144, no. 3, pp. 15. https://doi.org/10.1061/(asce)ei.1943-5541.0000364

[14] Steiner, M., Kanai, J., Hsu, C., Ledet, E., Morris, J., Anderson, M., Miller, S., Anderson, K., and Bagepalli, B. (2015). Preparing engineering students for professional practice: Using capstone to drive continuous improvement. International Journal of Engineering Education, vol. 31, no. 1, pp. 154-164.

[15] Sunthara, K., Vishnu, N. S. (2019). Sustainable employability skills for civil and other engineering professionals in the global market. International Journal of Civil Engineering and Technology, vol. 10, no. 1, pp. 1074-1080.

[16] Zaharim, A., Omar, M., Yusoff, Y., Muhamad, N., Mohamed, A., and Mustapha, R. (2010). Practical Framework of Employability Skills for Engineering Graduate in Malaysia. IEEE EDUCON Education Engineering 2010 - The Future of Global Learning Engineering Education. April-2010, Madrid, Spain. https://doi.org/10.1109/educon.2010.5492478

[17] Gómez-Urquizo, H. (2018). Propuesta de medición y evaluación de resultados de aprendizaje según criterios de ABET y ASIIN. 16th LACCEI International Multi-Conference for Engineering, Education and Technology: "Innovation in Education and Inclusion". July2018, Lima, Perú. https://doi.org/10.18687/laccei2018.1.1.435

[18] Pant, I. and Baroudi, B. (2008). Project management education: The human skills imperative. International Journal of Project Management, vol. 26, no. 2, pp. 124-128. https://doi. org/10.1016/j.ijproman.2007.05.010 
[19] Troy, C., Jesiek, K., Boyd, J., Trellinger, N., and Essig, R. (2016). Writing to learn engineering: Identifying effective techniques for the integration of written communication into engineering classes and curricula (NSF RIGEE project). 121st ASEE Annual Conference and Exposition Conference Proceedings, June-2016, Indianapolis, Indiana, USA. https://doi.org/10.18260/p.27060

[20] Hadgraft, R. (2017). Rethinking Accreditation Criteria to Focus on Design. 7th World Engineering Education Forum (WEEF 2017), November-2017, Kuala Lumpur, Malaysia. https://doi.org/10.1109/weef.2017.8467080

[21] AlMunifi, A., Aleryani, A. (2019). Knowledge Skills Level of Graduate Civil Engineers Employers and Graduates' Perceptions. International Journal of Engineering Pedagogy, vol. 9, no. 1, pp. 84-101. https://doi.org/10.3991/ijep.v9i1.9744

[22] Gunduz, M., and Yahya, A. (2018). Analysis of project success factors in construction industry. Technological and Economic Development of Economy, vol. 24, no. 1, pp. 67-80. https://doi.org/10.3846/20294913.2015.1074129

[23] Diamond, R. (2013). Designing and Assessing Courses and Curricula: A Practical Guide, 3rd edition, vol. 53, no. 9. San Francisco, CA.

[24] Brière, S., Proulx, D., Flores, O., and Laporte, M. (2015). Competencies of project managers in international NGOs: Perceptions of practitioners. International Journal of Project Management, vol. 33, no. 1, pp.116-125. https://doi.org/10.1016/j.ijproman.2014.04.010

[25] Engineers Australia (2008). Competency Standard for Professional Engineer. Engineers Australia Accreditation Board.

[26] Brill, J., Bishop, M., and Walker, A. (2006). The competencies and characteristics required of an effective project manager: A Web-Based Delphi Study. Educational Technology Research and Development, vol. 54, no. 2, pp. 115-140. https://doi.org/10.1007/s11423-0068251-y

[27] Sunindijo, R. (2015). Project manager skills for improving project performance. International Journal of Business Performance Management, vol. 16, no. 1, pp. 67-83. https://doi. org/10.1504/ijbpm.2015.066041

[28] ASCE (2008). American Society of Civil Engineering Body of Knowledge for the 21st Century. American Society of Civil Engineers.

[29] ASIIN (2012). Civil Engineering, Geodesy, and Architecture - Subject-Specific Criteria. Accreditation Agency for Degree Programmes in Engineering, Informatics, Natural Sciences, and Mathematics (ASIIN).

[30] Sumner, M., and Powell, A. (2013). What project management competencies are important to job success? 19th Americas Conference on Information Systems AMCIS 2013 - Hyperconnected World Anything, Anywhere, Anytime, August-2013, Chicago, Illinois.

[31] Taheri, P. (2018). Project-based approach in a first-year engineering course to promote project management and sustainability. International Journal of Engineering Pedagogy, vol. 8, no. 3, pp. 104-119. https://doi.org/10.3991/ijep.v8i3.8573

[32] Maqsoom, A., Wazir, J., Choudhry, M., Thaheem, M., and Zahoor, H. (2020). Influence of Perceiver Fairness on Contractors' Potential to Dispute: Moderating Effect of Engineering Ethics. Journal of Construction, Engineering, and Management, vol. 146, no. 1, pp. 1-11. https://doi.org/10.1061/(asce)co.1943-7862.0001740

[33] Stelios, S., and Christodoulou, A. (2020). Teaching professional integrity: An empirical study on engineering students. International Journal of Engineering Pedagogy, vol. 10, no. 3, pp. 98-105. https://doi.org/10.3991/ijep.v10i3.12013

[34] Okedara, K., Ejohwomu, O., and Chain, P. (2020). Ethics and Stakeholder Engagement for Industry/Construction 4.0: A Systematic Review. The Construction Industry on the Fourth Industrial Revolution, pp. 577-587. https://doi.org/10.1007/978-3-030-26528-1 59 


\section{Authors}

Miguel A. Gómez is a Civil Engineer and Bachelor of Science Engineering from the Pontificia Universidad Católica de Valparaíso. He is a researcher and professor at the School of Civil Engineering at the Pontificia Universidad Católica de Valparaíso, Chile. His current research is Structural Engineering and Engineering Education.

Rodrigo F. Herrera is a Civil Engineer and Bachelor of Science Engineering from the Pontificia Universidad Católica de Valparaíso and has a Master's in project management at the University of Viña del Mar. He is currently a Ph.D. candidate in Engineering Sciences at the Pontificia Universidad Católica de Chile and Universitat Politécnica de Valencia. He is currently professor of the courses "Planning and Project Control", "Project Management", and "Lean Project Management" at the School of Civil Engineering at the Pontificia Universidad Católica de Valparaíso, Chile. His current research is AEC Technologies, Lean Project Management, and Engineering Education.

Edison Atencio is a Civil Engineer and Bachelor of Science Engineering from the Pontificia Universidad Católica de Valparaíso and has a Master's in Industrial Engineering and is currently a Ph.D. candidate in Industrial Engineering at the Pontificia Universidad Católica de Valparaíso. He is currently professor courses "Applied Computer Science", "Planning and Project Control" and "Preparation and Project Evaluation" at the School of Civil Engineering at the Pontificia Universidad Católica de Valparaíso, Chile. His current research is AEC Technologies, Project Management, and Engineering Education.

Felipe C. Muñoz-La Rivera is Civil Engineer a Bachelor of Science Engineering from the Pontificia Universidad Católica de Valparaíso and Master in BIM Management and Ph.D. candidate in Civil Engineering at Universitat Politécanica de Catalunya. His current research is AEC Technologies, Building Information Modeling (BIM), Project Management, and Engineering Education.

Article submitted 2020-04-27. Resubmitted 2020-06-19. Final acceptance 2020-06-24. Final version published as submitted by the authors. 